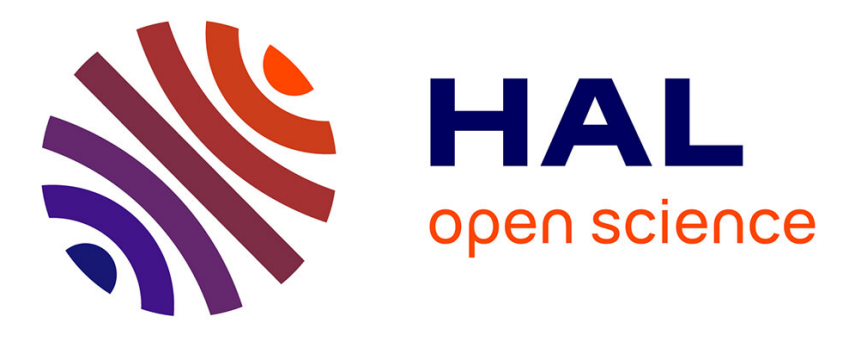

\title{
Systematic study of interaction of the neutral form of anilines with undecylcalix[4]resorcinarene derivatives by means of potentiometry
}

Jerzy Radecki, Remalakshmy Poduval, Katarzyna Kurzatkowska, Magdalena Stobiecka, Wim F.A. Dehaen, Wim Dehaen, Hanna Jadwiga Radecka

\section{To cite this version:}

Jerzy Radecki, Remalakshmy Poduval, Katarzyna Kurzatkowska, Magdalena Stobiecka, Wim F.A. Dehaen, et al.. Systematic study of interaction of the neutral form of anilines with undecylcalix[4]resorcinarene derivatives by means of potentiometry. Supramolecular Chemistry, 2010, 22 (07-08), pp.413-419. 10.1080/10610278.2010.486437 . hal-00602598

\section{HAL Id: hal-00602598 https://hal.science/hal-00602598}

Submitted on 23 Jun 2011

HAL is a multi-disciplinary open access archive for the deposit and dissemination of scientific research documents, whether they are published or not. The documents may come from teaching and research institutions in France or abroad, or from public or private research centers.
L'archive ouverte pluridisciplinaire HAL, est destinée au dépôt et à la diffusion de documents scientifiques de niveau recherche, publiés ou non, émanant des établissements d'enseignement et de recherche français ou étrangers, des laboratoires publics ou privés. 


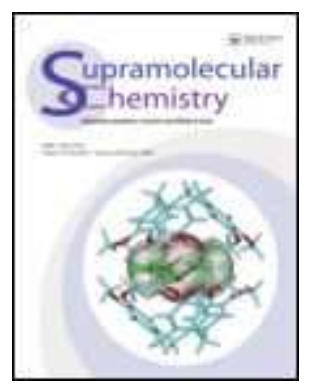

\section{Systematic study of interaction of the neutral form of anilines with undecylcalix[4]resorcinarene derivatives by means of potentiometry}

\begin{tabular}{|c|c|}
\hline Journal: & Supramolecular Chemistry \\
\hline Manuscript ID: & GSCH-2010-0030.R1 \\
\hline Manuscript Type: & Special Issue Paper \\
\hline $\begin{array}{r}\text { Date Submitted by the } \\
\text { Author: }\end{array}$ & 12-Apr-2010 \\
\hline Complete List of Authors: & $\begin{array}{l}\text { Radecki, Jerzy; Institute of Animal Reproduction and Food Research } \\
\text { Polish Academy of Scieneces, Department of Biosensors } \\
\text { Poduval, Remalakshmy; Cochin University, Chemistry Department } \\
\text { Kurzatkowska, Katarzyna; Institute of Animal Reproduction and } \\
\text { Food Research, Department of Biosensors } \\
\text { Stobiecka, Magdalena; Institute of Animal Reproduction and Food } \\
\text { Research, Department of Biosensors } \\
\text { Dehaen, Wim F.A.; University of Leuven, Chemistry Department } \\
\text { Dehaen, Wim; University of Leuven, Chemistry Department } \\
\text { Radecka, Hanna; Institute of Animal Reproduction and Food } \\
\text { Research, Department of Biosensors }\end{array}$ \\
\hline Keywords: & $\begin{array}{l}\text { undecylcalix[4]resorcinarene, aniline derivatives, molecular } \\
\text { recognition, potentiometry, neutral analytes }\end{array}$ \\
\hline
\end{tabular}

\section{$\checkmark$ ScholaroNE" \\ Manuscript Central}




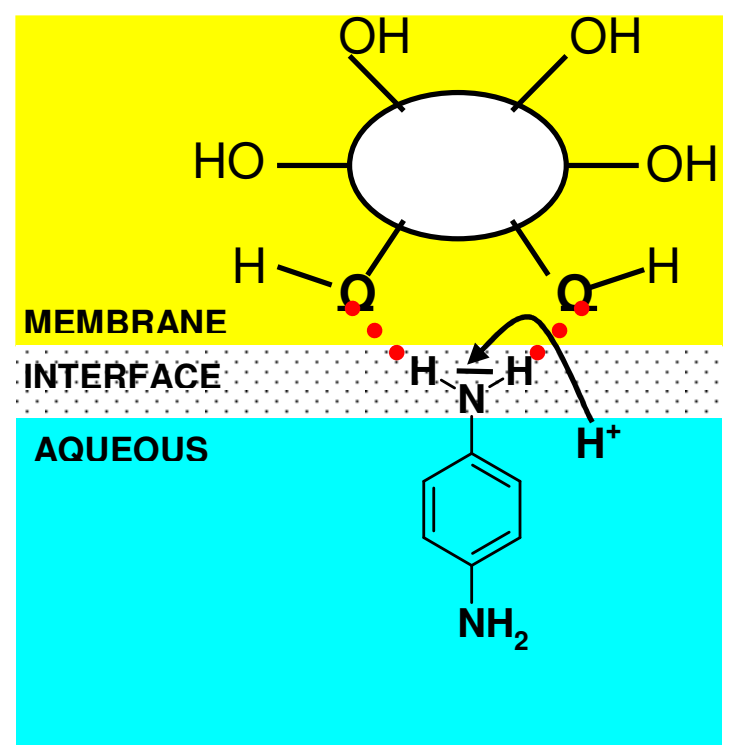




\title{
Systematic study of interaction of the neutral form of anilines with undecylcalix[4]resorcinarene derivatives by means of potentiometry
}

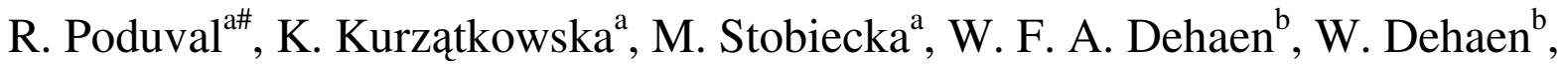 \\ H. Radecka ${ }^{a}$, J. Radecki ${ }^{\text {a* }}$ \\ ${ }^{a}$ Institute of Animal Reproduction and Food Research, Polish Academy of Science, Olsztyn, \\ Poland; ${ }^{b}$ Chemistry Department, University of Leuven, Leuven, Belgium \\ *Corresponding Author: j.radecki@pan.olsztyn.pl \\ ${ }^{\#}$ PhD fellow of EU grant Marie-Curie Transfer of Knowledge, No: MTKD-CT-2006-042708
}

\begin{abstract}
The elucidation of the mechanism of potentiometric signals generation by liquid membrane electrodes incorporating undecylcalix[4]resorcinarene derivatives upon stimulation by uncharged aniline derivatives is the main aim of the research presented. A series of molecules which play the role of host and guests in the molecular recognition process which occurring at the aqueous / organic membrane interface were explored. It was proved that in the conditions where all aniline derivatives exist as uncharged molecules, cationic potentiometric signals were observed for all undecylcalix[4]resorcinarene liquid membrane electrodes. The main parameters crucial for this phenomenon are the acidity / basicity of the hosts as well as the guests. The lipophilicity of the guests plays a secondary role.
\end{abstract}

Keywords: undecylcalix[4]resorcinarene, aniline derivatives, molecular recognition, potentiometry, neutral analytes

\section{Introduction}

Molecular recognition refers to the specific noncovalent interactions such as:

hydrogen bonding, hydrophobic forces, van der Waals forces, $\pi$ - $\pi$ interactions, and electrostatic effects between two or more molecules $(1,2)$.

A receptor (host) can recognize a substrate (guest) on the base of the structural complementarities of the two molecular species. The design and characterization of synthetic host-guest pairs still is an open challenge in supramolecular chemistry.

Different techniques like NMR, mass spectroscopy, X-Ray crystallography, laser technologies, isothermal titration calorimetry, cyclovoltammetry and also computational methods have been employed to study supramolecular interactions (3-7). Potentiometry also is of importance in this regard (8). Potentiometric techniques help to provide an insight into 
the recognition at the liquid-liquid interface where the mechanism of generation of a potentiometric signal depends on the charge separation between the two phases which in turn is the result of a selective transfer of guest molecule from the aqueous to the organic phase. Vital components of such type of sensors are poly(vinyl chloride) (PVC) membranes modified with specific ionophores, which are responsible for important from analytical point of view parameters such as: selectivity and sensitivity as well as the time of response and reproducibility. Different types of molecules such as calixarenes $(9,10)$, macrocyclic polyamines (11-13), calixpyrroles (14), corroles (15) and calix[4]phyrins (16) were applied as a host in PVC supported liquid membranes. The chemical structure complementarities between host and specific guest are crucial in selective molecular recognition. The structure of host is usual read out by the guest.

Potentiometric sensors have some outstanding advantages including simple design and operation, wide linear dynamic range, relatively fast response and rational selectivity. Because of this, their construction is particularly interesting from the perspective of the supramolecular chemists. The potentiometric sensors could be applied as useful tools for observation of molecular recognition process at the border of two phases.

In classical potentiometry, the analytes are ionic species. So far, there are only few examples of the potentiometric recognition of neutral molecules. In a pioneering paper by Umezawa and co-workers, the possibilities of potentiometric signal generation by polymeric membranes modified with quaternary ammonium salts (17) and lipophilic polyamines (18, 19), after their stimulation with uncharged phenol derivatives, were described for the first time. This research dealt with permanently charged ligands (tetra-alkylammonium salts), or formally neutral amines which gain a plus charge after being in contact with the aqueous phase (e.g. macrocyclic polyamines). Next, new classes of ligands which are able to recognize undissociated nitrophenols and generate changes of membrane potential were described by our group. These new ligands belong to the family of calix[4]pyrroles, corroles, calix[4]phyrins and metaloporphyrins (20-26). The first three of them are tetrapyrrolic macrocyclic compounds and are members of a very wide family of porphyrin analogues. They are well known as sensitive and selective receptors for anions (27-32).

In general, the host-guest recognition process in the case of these compounds could be realized mainly by the creation of hydrogen bonds between the ligand and target molecules, and also by electrostatic interactions, Lewis acid-base and $\pi-\pi$ electron interactions (33-36).

In our previous paper, concerning the generation of a potentiometric signals by neutral analytes, we have shown that PVC supported liquid membrane electrode incorporated with 
undecylcalix[4]resorcinarene generate cationic potentiometric signals in the presence of unprotonated diaminobenzene isomers (37). The para-isomer with the highest basicity generates the highest potentiometric response. We confirmed by spectroscopic methods that the potentiometric signals were generated based on the formation of a supramolecular complex between the undecylcalix[4]resorcinarene host and the diaminobenzene isomer guest at the organic-aqueous interfaces (37).

In the same paper we have suggested a hypothetical mechanism of cationic potential signal generation as a result of intermolecular recognition process between the undecylcalix[4]resorcinarene in the polymeric membrane and diaminobenzene isomers in solution. The observed recognition process is selective and allows distinguishing between the particular isomers (37).

The main goal of our research was showing the generation of potentiometric signals by uncharged molecules and possibility of changing the direction of potentiometric signals by changing the nature of host and guest molecules.

The anionic potentiometric signals were observed when macrocycles containing nitrogen atoms were applied as the host molecules and phenol derivatives play role of the guests (1725). When macrocycles containing phenolic groups were applied as the host molecules and aniline derivatives play role of the guests - the cationic potentiometric responses were observed (37).

Here, we summarize the results of the systematic potentiometric investigation of the intermolecular recognition processes at the water/polymer membrane border between some derivatives of undecylcalix[4]resorcinarenes and neutral (unprotonated) forms of aniline derivatives such as: diaminobenzene, chloroaniline, hydroxyaniline, methylaniline, methoxyaniline and nitroaniline. In particular, we focused on the effect of ligand and analyte structure on the generation of the membrane potential changes. The structures of the host molecules are illustrated in Figure 1.

\section{Experimental}

\section{Reagents and materials}

The receptor (host) molecules used for this study are tetra-undecyl-tetra- $p$ nitrophenylazocalix[4]resorcinarene (Ligand 1), tetra-undecylcalix[4]resorcinarene (Ligand 2), tetra-undecyl-tetra- $p$-phenylazocalix[4]resorcinarene (Ligand 3), tetra-undecyl-tetrabromocalix[4]resorcinarene (Ligand 4), tetra-undecyl-tetra-hydroxycalix[4]resorcinarene 


\section{Electrode preparation and potential measurements}

The PVC membranes were prepared with using the following components: $1 \%$ (wt.) of the host, $66 \%$ (wt.) of plasticizer, and 33\% (wt.) of PVC. All components were dissolved in $2 \mathrm{ml}$ freshly distilled THF and the homogenous mixture was poured into a glass ring of $30 \mathrm{~mm}$ diameter and left for $24 \mathrm{~h}$ to allow THF to evaporate. The membranes obtained were of 100 $\mu \mathrm{m}$ (ca.) thickness. Circles of $6 \mathrm{~mm}$ diameter were cut from the membrane and directly mounted on to a liquid membrane-type Philips ISE body (Glasbläserie Möller, Zürich, Switzerland). All potentiometric measurements were performed at room temperature $\left(\sim 20^{\circ} \mathrm{C}\right)$ on a multi-channel station, EMF-16 (Lawson Labs). A double junction Ag $\mid \mathrm{AgCl}$ electrode was used as the reference electrode. The electrode cell assembly is presented bellow:

$\mathrm{Ag} / \mathrm{AgCl}$ | $3 \mathrm{M} \mathrm{KCl} \mid 1 \mathrm{M} \mathrm{CH}_{3} \mathrm{COOLi}$ || sample solution I membrane $10.1 \mathrm{M} \mathrm{KCl} \mid \mathrm{Ag} / \mathrm{AgCl}$

The electrodes were conditioned in $1.0 \times 10^{-1} \mathrm{M}$ phosphate buffer $(\mathrm{pH} 7.0)$ for $24 \mathrm{~h}$. The calibrating solutions of the guest molecules were prepared in $1.0 \times 10^{-1} \mathrm{M}$ phosphate buffer, pH 7.0.

\section{Results and discussion}

Cationic potentiometric responses of PVC supported liquid membranes incorporating undecylcalix[4]resorcinare hosts in the presence of neutral forms of aniline derivatives Our previous study on the of potentiometric responses of liquid membrane electrodes incorporating with undecylcalix[4]-resorcinarene in the presence of diaminobenzene isomers 
were performed at $\mathrm{pH} 3.0$ and $\mathrm{pH}$ 7.0. The potentiometric signals were observed only at $\mathrm{pH}$ 7.0, where all guests exist in uncharged form. The potentiometric signals were not observed at $\mathrm{pH}$ 3.0, where all isomers exist in the cationic form (37). Therefore, all potentiometric measurements presented here were performed at $\mathrm{pH}$ 7.0. Under such conditions all aniline derivatives investigated exist in water almost entirely as the neutral (unprotonated) compounds (Table 1).

Figure 2 illustrates an example of potentiometric responses of PVC membranes containing Ligand 1 towards of diaminobenzene isomers. The results obtained for all aniline derivatives and all type of membranes studied are collected in Table 2. It has been proved that all types of membranes generate cationic responses towards uncharged aniline derivatives.

Comparison of the results for all analytes showed the general tendency: with the increase of the analyte basicity, the response increases. In most cases, the para isomer generates the highest response. For ortho and meta isomers it is difficult to estimate which one generates higher signal (Table 2).

Based on the results obtained we can show only general qualitative relationship between potentiometric signals and acidity of the guests. This is because of the others parameters such as lipophilicity, steric hindrance also have some influence of the phenomenon studied.

Similar trends we have observed in the case of membranes modified with pyrrole containing macrocycles stimulated with isomers of dihydroxybenzene $(21,23)$.

An explanation of the weak response of membranes after stimulation with ortho isomers is the possibility to form intramolecular hydrogen bonds. Because of that, the formation of intermolecular (host-guest) hydrogen bonds is relatively more difficult.

We have not observed the relationship between potentiometric responses and partition coefficients of the aniline guests. This is evident that phenomenon observed is govern by acidity / basicity of the host /guest. The hydrophobicity of the guests plays a secondary role.

The weakest response was observed for nitro- and chloro- derivatives of aniline. These guests are the strongest acids among the investigated compounds. In the case of membranes modified with pyrrole containing macrocycles stimulated with nitro phenol, the opposite phenomenon was observed. The strongest responses were observed in the case of guests with the strongest acidity (21).

The ligands under study have different structures of the upper rim. In Ligand 1 there are dihydroxybenzene substituents in which the $\mathrm{OH}$ groups are in position 1 and 3 in relation to each other. These distances make intramolecular hydrogen bonds very weak. Additionally 


\section{Ligand $1>$ Ligand $2>$ Ligand 3, Ligand $4>$ Ligand 5}

This sequence indicates that an increase of the acidity of the phenol groups causes an increase of the potentiometric response value.

We observed the strongest response for the membrane modified with Ligand 1 containing in its structure dihydroxybenzene substituted with the electron-withdrawing azonitrobenzene. The acidity of these $\mathrm{OH}$ groups is the highest.

Next in this sequence is Ligand 2 with unsubstituted resorcinol. In this case the acidity of the $\mathrm{OH}$ group is lower than in Ligand 1, but the accessibility of Ligand 2 for analytes is much easier. In consequence, the creation of a hydrogen bond $(\mathrm{H} \ldots \mathrm{O} \ldots \mathrm{H} \ldots \mathrm{N})$ between analyte and ligand is relatively easy. The Ligand 3 contains in its structure a resorcinol substituted with azobenzene. This causes an increase of the phenolic acidity, but at the same time, the presence of a rather large substituent hinders the access of $\mathrm{OH}$ group for analyte molecules. The signal value generated by membrane modified with Ligand 3 is a result of these two opposite effects.

Ligand 4 containing the bromo-derivatives of resorcinol in their structure is next in the sequence of the response value. In this case, similarly as it was in the previous one, two factors compete: from one side the inductive and mezomeric effects, which causes an increase 
of the acidity of the phenol group and the large bromine atom, which is a significant hindrance for the approach of the analyte.

The lowest response we have obtained for the membrane modified with Ligand 5 which possesses pyrogallol (trihydroxybenzene) in its structure. In this ligand, the strong intramolecular hydrogen bonds are present. As the consequence, this lowers overall phenolic acidity. Because of this, the formation of a supramolecular complex with the analyte is relatively the most difficult among the ligands under study.

Analysis of the data obtained shows that there is no direct relation between the lipophilicity of the amine guests and the values of the signal generated by them.

However, the low lipophilicity of para-hydroxyaniline may be one of the reasons of its weak potentiometric response in spite of its high basicity (Table 2).

Checking of the possibility of transport of para-anisidine through the PVC membrane modified with tetra-undecyl-tetra-p-nitrophenylazocalix[4]resorcinarene

The possibility of transporting para-anisidine across the tetra-undecyl-tetra-pnitrophenylazocalix[4]resorcinarene (Ligand 1) membrane was checked by performing a long-term experiment in two solutions (1) $1.0 \times 10^{-1} \mathrm{M} \mathrm{KCl}$ and solution (2) $1.0 \times 10^{-4} \mathrm{M}$ of para-anisidine in $1.0 \times 10^{-2} \mathrm{M}$ phosphate buffer $\mathrm{pH} 7.0$. The cells were separated by a piece of membrane containing Ligand 1. The transport of para-anisidine through the modified membrane was monitored by UV-Vis measurements. After $24 \mathrm{~h}$ the $\mathrm{KCl}$ solution was free of para-anisidine. This means that para-anisidine is not able to penetrate through a PVC membrane modified with Ligand 1 during this time interval. Therefore, it might be concluded that the potentiometric signals observed in the present study were not generated as a result of diffusion of the analyte through the polymeric membranes, but there are a consequence of the supramolecular recognition phenomena occurring at the organic/aqueous interface.

\section{The mechanism of the generation of the potentiometric signal of undecylcalix[4]resorcinare modified membranes after stimulation by unprotonated derivatives of anilines}

Based on the obtained results and data from the literature we propose the following mechanism of cationic potentiometric signal generation by membranes modified with derivatives of undecylcalix[4]resorcinarene after stimulation with unprotonated aniline derivatives. In the first step, during conditioning, some of the phenolic groups of 
undecylcalix[4]resorcinarene derivatives, located at the surface of polymeric membranes, dissociate and the membranes gain a minus charge. Such type of dissociation of $\mathrm{OH}$ groups at the upper rim of undecylcalix[4]resorcinarene was already reported (40-42). In the next step, a network of hydrogen bonds between the aniline derivatives and the phenolate groups is created. Thus, a supramolecular complex of undecylcalix[4]resorcinarene and aniline derivatives is formed at the water/membrane interface. The amino groups are donors of hydrogen atoms in hydrogen bonds. Their polarity correlates with the acidity of phenol groups.

The formation of such a hydrogen bond network in one phase was already reported $(43-45)$. The measurements were carried out at $\mathrm{pH}$ 7.0. Under this condition, all of the investigated anilines exist in solution mostly as unprotonated compounds (Table 1). The increase of the electron density at the amine nitrogen atom upon complex formation causes an increase of its basicity and this is the driving force for transferring the proton from the surface of the aqueous phase to the surface of the organic (membrane) phase. Proton transfer leads to an increase of the plus charge on the membrane surface, and we can observe the generation of a potentiometric cationic signal.

Generally, the proposed mechanism is based on three steps.

The first one concerns dissociation of some phenolic groups from the upper rim of the investigated resorcinarene ligands.

\section{(I) $\mathrm{HostOH}_{\text {membrane }}+\mathrm{H}_{2} \mathrm{O} \leftrightarrow \mathrm{HostO}^{-}+\mathrm{H}_{3} \mathrm{O}^{+}$}

The next step consists of the transfer of the analyte from the bulk solution to the interface and formation of a supramolecular complex between the ligand and the analyte through hydrogen bonds.

(II) $\mathrm{HostO}_{\text {interface }}^{-}+\mathrm{NH}_{2}$ - $\mathrm{Ar} \leftrightarrow \mathrm{HostO}^{-}----\mathrm{H}_{----N H-A R}$ interface

A consequence of this is the increase of the basicity of the nitrogen atom of the supramolecular complex, and its protonation.

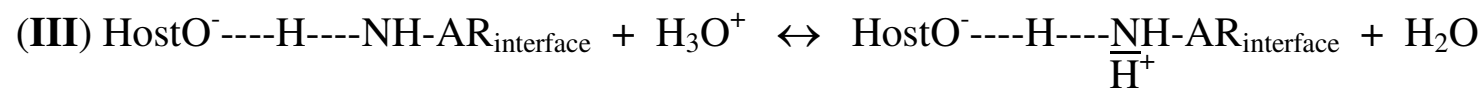

The confirmation of the first step is based on the results we have obtained with the membrane modified with Ligand $\mathbf{1}$ in which the acidity of phenolic groups is the highest. The results we 
observed for bromo- and azobenzene- derivatives of investigated undecylcalix[4]resorcinarene shows that the accessibility of phenols groups is a very important parameter for the intermolecular recognition process which is taking place between the investigated ligands and the analytes.

The weakest response we have observed in case of membranes modified with Ligand 5 which possesses in its structure trihydroxybenzene could be explain by the low acidity and the possibility to form the intramolecular hydrogen bonds. This is a relatively strong energetic barrier for the described phenomenon.

The second step of the proposed mechanism, which relies on proton transfer from the water to the organic phase, is supported by the fact that regardless of the ligand, the strongest signal was observed for the strongest bases between compounds under study. The results obtained show that the lipophilicity of the analytes is not a crucial parameter.

\section{Conclusions}

The systematic work we have carried out (21-25) on the study of the potentiometric signal generated by uncharged molecules was inspired by the first pioneer papers by Umezawa (1820 ) on the anionic potentiometric responses of membranes modified with macrocyclic polyamines or quaternary ammonium salts stimulated with undissociated dihydroxybenzenes. It was proved that PVC supported membranes incorporating hosts with amino groups upon stimulation with phenolic guests generate anionic potentiometric signals. The base of this phenomenon is a proton transfer from supramolecular complexes located at the interface towards the aqueous phase.

In this paper we proved that membranes modified with hosts possessing phenolic groups generate cationic potentiometric responses upon stimulation by uncharged guests possessing $\mathrm{NH}_{2}$ groups. In this case, the base of the potentiometric signal generation relies on the proton transfer from the aqueous phase on the supramolecular complexes located at the interface.

In both cases, the acidity and basicity of the ligands, as well as the analytes, are crucial parameters, which govern these phenomena. The shape of the cavity of the macrocyclic ligand is also significant. The lipophilicity of the analytes plays a secondary role.

Based on the Umezawa papers, as well as our already published work and the research presented, we can conclude that the generation of potentiometric signals by uncharged molecules is governed by the transport of protons between the aqueous and membrane / 
aqueous interface. The acidity / basicity of the hosts decide about the direction of the transfer of protons.

\section{Acknowledgements}

The work was supported by European Union Marie Curie Transfer of Knowledge Research Grant MTKD-CT2006-042708, the Polish Ministry of Sciences and Higher Education no. 105/6.PR. UE/2007/7, and Institute of Animal Reproduction and Food Research of the Polish Academy of Science, Olsztyn, Poland. W.F.A.D. and W.D. thank the University of Leuven, the Ministerie voor Wetenschapsbeleid and the F.W.O. for continuing support.

\section{References}

(1) Gale, P.A. Coord. Chem. Rev. 2003, 240, 181-212.

(2) Anitha, B.; Subramanian, E, Sens. Actuators, B 2005, 107, 605-609.

(3) Brunklaus, G.; Koch, A.; Sebastiani, D.; Spiess, H.W. Chem. Phys. 2007, 9, 45454551.

(4) Garcia-Garrido, S. E.; Caltagirone, C.; Light, M.E.; Gale, P.A. Chem. Commun. 2007, $14,1450-1452$.

(5) Dehaen, W.; Gale, P.A.; Garcia-Garrido, S.E.; Kostermans, M.; Light, M.E. New J. Chem. 2007, 31, 691-696.

(6) Wong, W.W.H.; Curiel, D.; Lai, S.W.; Drew, M.G.B.; Beer, P.D. Dalton Trans. 2005, $4,774-281$.

(7) Zhao, Y.; Truhlar, D.G. Chem. Phys. 2008, 10, 2813- 2819.

(8) Yu, R.-Q.; Zhang, Z.-R.; Shen, G.-L. Sens. Actuators, B 2000, 65,150-153.

(9) De Macro, R.; Clarke, G.; Pejcic, B. Electroanalysis 2007, 19, 1987-2001.

(10) Kwan, P.; Man, L.; Wong, S. Sensors 2008, 8, 5313-5335.

(11) Odashima, K.; Yagi, K.; Thoda, K.; Umezawa, Y. Anal. Chem. 1993, 65, 1074-1093.

(12) Bulgariu, L.; Radecka, H., Pietraszkiewicz, M.; Pietraszkiewicz, O. Anal. Lett. 2003, 36, 1325-1334.

(13) Radecka, H.; Szymańska, I.; Pietraszkiewicz, M.; Pietraszkiewicz, O.; Aoki, H.; Umezawa; Y. Chem. Anal. (Warsaw) 2005, 50, 85-102.

(14) Szymańska, I.; Radecka, H.; Radecki, J.; Gale, P.A.; Warriner, C.N. J. Electroanal. Chem. 2006, 591, 223-228.

(15) Radecki, J.; Stenka, I.; Dolusic, E.; Dehaen, W.; Plavec, J. Combin. Chem. \& Throughpt Screen 2004, 7, 375-381. 
(16) Szymańska, I.; Orlewska, Cz.; Janssen, D.; Dehaen, W.; Radecka, H. Electrochim. Acta 2008, 53, 7932-7940.

(17) Ito, T.; Radecka, H.; Tohda, K.; Odashima, K.; Umezawa, Y. J. Am. Chem. Soc. 1998, 120, 3049-3059.

(18) Odashima, K.; Naganava, R.; Radecka, H.; Kataoka, M.; Kimura, E.; Koike, T.; Tohda, K.; Tange, M.; Furta, H.; Sessler, J.L.; Yagi, K.; Umezawa, Y. Supramol. Chem. 1994, 4, 101-113.

(19) Ito, T.; Radecka, H.; Umezawa, K.; Kiura, T.; Yashiro, A.; Lin, A.; Kataoka, X. M.; Kiura, E.; Sessler, J.L.; Yagi, K.; Umezawa Y. Anal. Sci. 1998, 14, 89-98.

(20) Piotrowski, T.; Radecka, H.; Radecki, J.; Depraetere, S.; Dehaen, W.; Mater. Sci. Eng. 2001, 18, 223-228.

(21) Radecki, J.; Radecka, H.; Piotrowski, T.; Depraetere, S.; Dehaen, W.; Plavec, J. Electroanalysis 2004, 16, 2073-2081

(22) Radecki, J.; Stenka, I.; Dolusic, E.; Dehaen, W.; Plavec, J. Combin. Chem. \& Throughpt Screen 2004, 7, 375-381.

(23) Piotrowski, T.; Radecka, H.; Radecki, J.; Depraetere, S.; Dehaen, W.; Anal. Lett. 2002, 35, 1895-1906.

(24) Radecki, J.; Stenka, I.; Dolusic, E.; Dehaen, W. Electrochim. Acta 2006, 51, 2282-2288.

(25) Radecki, J.; Dehaen, W. J. Combin. Chem. \& Throughpt Screen 2006, 9, 399-406.

(26) Saraswathyamma, B.; Pająk, M.; Radecki, J.; Maes, W.; Dehaen, W.; Kumar, K.G.; Radecka, H. Electroanalysis 2008, 20, 2009-2015.

(27) Gale, P.A.; Anzenbacher Jr, P.; Sessler, J.L. Coord. Chem. Rev. 2001, 222, 57-102.

(28) Sessler, J.L.; Camiolo, S.; Gale, P.A. Coord. Chem. Rev. 2003, 240, 17-55.

(29) Custelcean, R.; Delmau, L.H.; Moyer, B.A.; Sessler, J.L.; Cho, W.S.; Gross, D.; Bates, G.W.; Brooks, S.J.; Light, M.E.; Gale, P.A. Angew. Chem. 2005, 117, 2593-2598.

(30) Gale, P.A.; Sessler, J.L.; Král, V.; Lynch, V. J. Am. Chem.Soc. 1996, 118, 5140-5141.

(31) Bucher, Ch.; Zimmerman, R.S.; Lynch, V.; Kral, V.; Sessler J.L. J. Am. Chem. Soc. 2001, 123, 2099-2100.

(32) Camiolo, S.; Coles, S.J.; Gale, P.A.; Hursthouse, M.B.; Sessler, J.L. Acta Crystallogr., Sect. E 2001, 57, 816-818.

(33) Woods, C.J.; Camiolo, S.; Light, M.E.; Coles, S.J.; Hursthouse, M.B.; King, M.A.; Gale, P.A.; Essex, J.W. J. Am. Chem. Soc. 2002, 124, 8644-8652.

(34) Choi, K.; Hamilton, A. D. Coord. Chem. Rev. 2003, 240, 101-110.

(35) Beer, P. D.; Cadman, J. Coord. Chem. Rev. 2000, 205, 131-155. 
(36) D’Ammico, A.; Di Natale, C.; Paolasse, R.; Macagnano, A.; Mantini, A. Sens. Actuators, B 2000, 65, 209-215.

(37) Kurzatkowska, K.; Radecka, H.; Dehaen, W.; Wąsowicz, M.; Grzybowska, I.; Radecki, J. Combin. Chem. \& Throughput Screen. 2007, 10, 604-610.

(38) Omar, O.; Ray, A. K.; Hassan, A. K.; Davis, F, Supramolecular Science 1997, 4 (3-4), 417-42.

(39) Irwin, Jacob L.; Sherburn, Michael S. J. Org. Chem. 2000, 65(2), 602-605.

(40) Mark, W.; Sugden; Richardson, T.H.; Davis, F.; Seamus, P.J.; Higson, P.J.; Faul, Ch.F.J. Colloid and Surfaces 2008, 321, 1-5.

(41) Davis, F.; Sterling Ch.J.M. Langmuir 1996, 12, 5365-5374.

(42) Stodeman, M.; Dhae, N. J. Chem. Soc. Faraday Trans 1998, 94, 899-903.

(43) Nachtigall, F.; Lazzarotto, M.; Nome, F. J. Brazil Chem. Soc. 2002, 13, 295-299.

(44) Akceylan, E.; Bahadir, M.; Yilmaz, M. J. Hazard. Mater. 2009, 162, 960-966.

(45) Gutasche, C.D.; Iqbal, M.; Alam, I. J. Am. Chem. Soc. 1987, 109, 4314-4320. 


\section{Figure 1.}

The chemical structure of host molecules under study, where $\mathrm{R}$ : $-\mathrm{C}_{11} \mathrm{H}_{23}$.

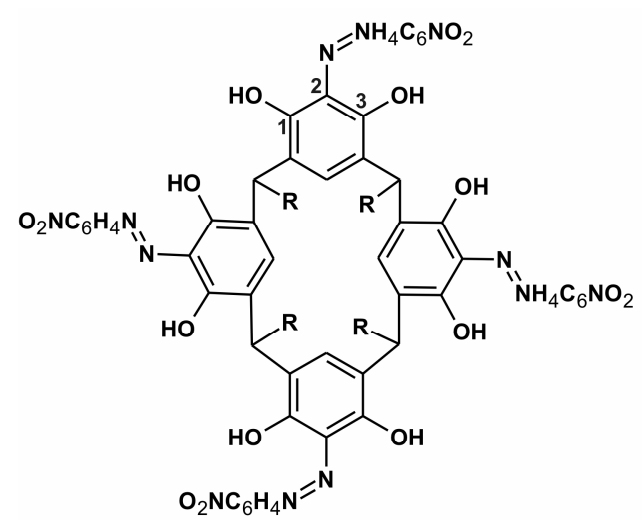

Ligand 1

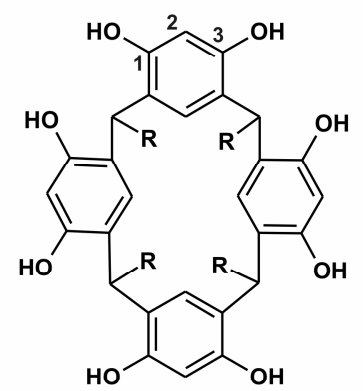

Ligand 2

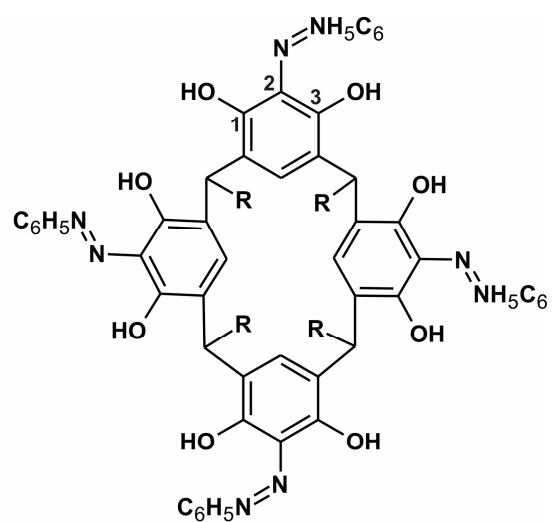

Ligand 3

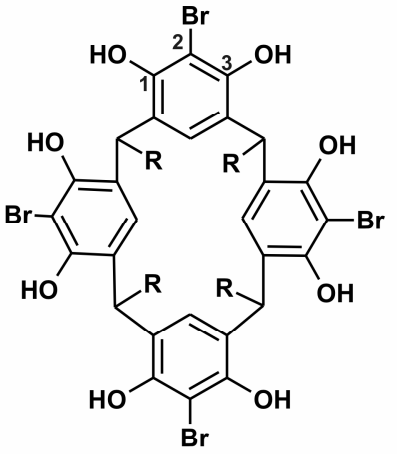

Ligand 4

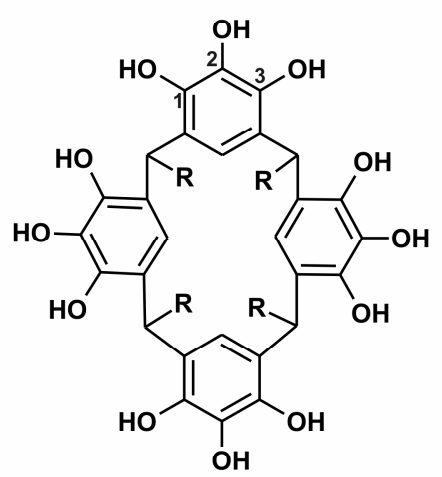

Ligand 5 


\section{Figure 2.}

Potential responses of PVC membranes plasticized with NPOE incorporated with Ligand 1

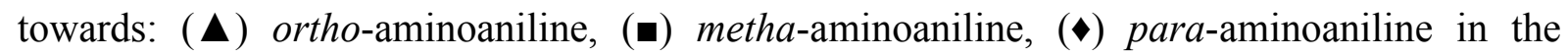
presence of $1.0 \times 10^{-2} \mathrm{M}$ phosphate buffer $\mathrm{pH} 7.0(\mathrm{n}=3,3.11<\mathrm{SD}<0.13)$

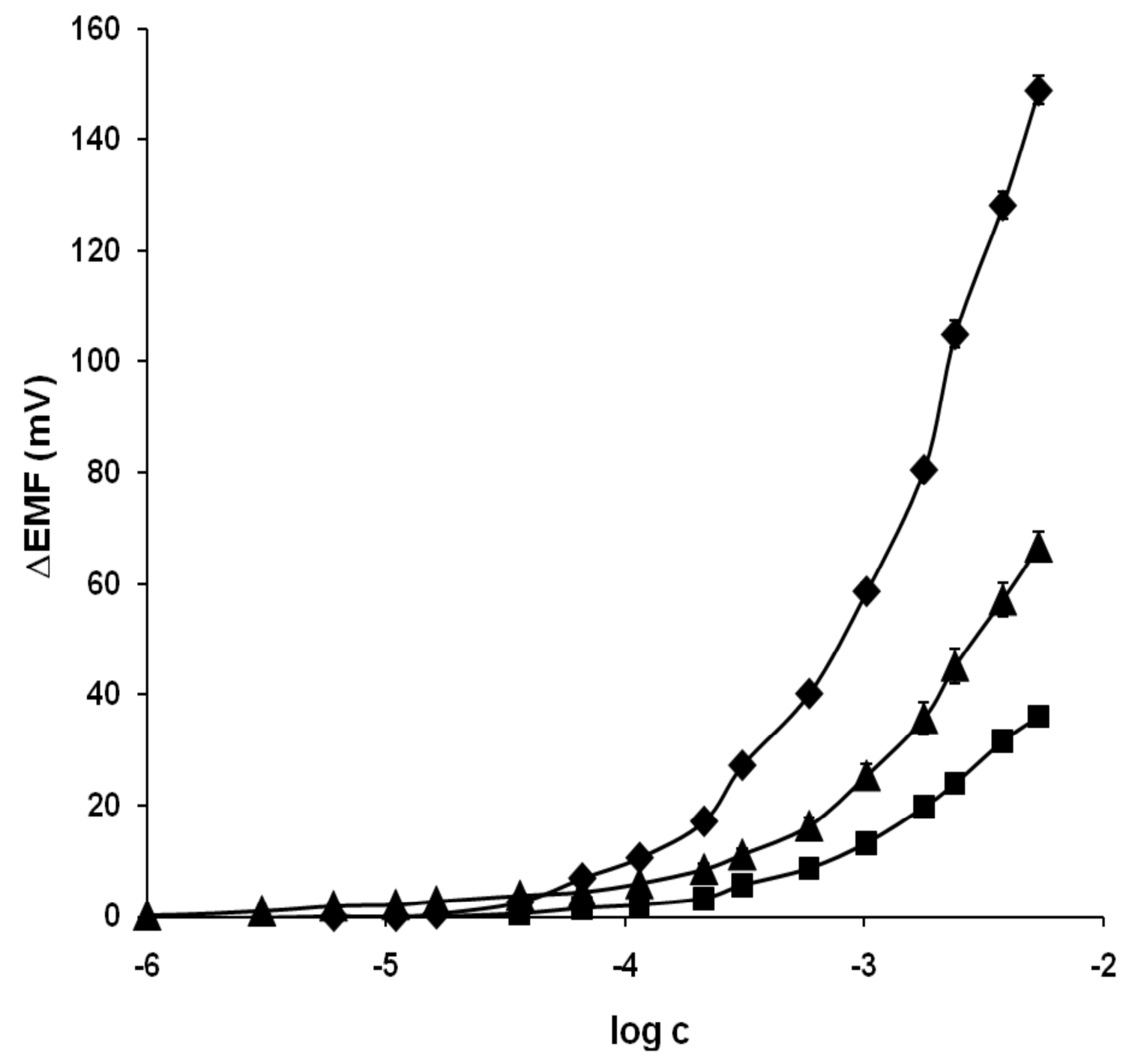


Table 1.

Percentage of protonated and neutral species at $\mathrm{pH}$ 7.0.

\begin{tabular}{|c|c|c|c|c|c|}
\hline \multirow{2}{*}{ S.No. } & \multirow{2}{*}{ Analyte } & \multirow{2}{*}{$\mathrm{p} K_{1}$} & \multirow{2}{*}{$\mathbf{p} K_{2}$} & \multicolumn{2}{|c|}{ pH 7.0} \\
\hline & & & & $\mathrm{RNH}_{2}(\%)$ & $\mathrm{RNH}_{3}^{+}(\%)$ \\
\hline 1 & $p$-nitroaniline & 1.02 & & 100.0 & 0.0 \\
\hline 2 & $o$-chloroaniline & 2.66 & & 100.0 & 0.0 \\
\hline 3 & $m$-chloroaniline & 3.52 & & 100.0 & 0.0 \\
\hline 4 & $p$-chloroaniline & 3.98 & & 99.9 & 0.1 \\
\hline 5 & $m$-anisidine & 4.20 & & 99.8 & 0.2 \\
\hline 6 & $o$-toluidine & 4.45 & & 99.7 & 0.3 \\
\hline 7 & $o$-anisidine & 4.53 & & 99.7 & 0.3 \\
\hline 8 & $o$-aminoaniline & 4.61 & 1.81 & 99.6 & 0.4 \\
\hline 9 & $m$-toluidine & 4.71 & & 99.5 & 0.5 \\
\hline 10 & aniline & 4.87 & & 99.3 & 0.7 \\
\hline 11 & $m$-aminoaniline & 5.01 & 2.56 & 99.0 & 1.0 \\
\hline 12 & $p$-toluidine & 5.08 & & 98.8 & 1.2 \\
\hline 13 & $p$-anisidine & 5.36 & & 97.8 & 2.2 \\
\hline 14 & $p$-hydroxyaniline & 5.48 & & 97.1 & 2.9 \\
\hline 15 & $p$-aminoaniline & 6.22 & 2.99 & 85.8 & 14.2 \\
\hline
\end{tabular}




\section{Table 2.}

The potentiometric response of PVC liquid membranes incorporating calixarene host generated in the presence of aniline derivatives; $\Delta \mathrm{E}[\mathrm{mV}]$.

\begin{tabular}{|c|c|c|c|c|c|c|c|}
\hline Guests & $\mathbf{p} K_{1}$ & $\log P_{o / w}$ & Ligand 1 & Ligand 2 & Ligand 3 & Ligand 4 & Ligand 5 \\
\hline$p$-diaminobenzene & 6.22 & -0.26 & 148.9 & 138.4 & 88.4 & 86.9 & 41.5 \\
\hline$p$-anisidine & 5.36 & 1.15 & 118.6 & 68.9 & 53.9 & 59.4 & 37.4 \\
\hline$m$-anisidine & 4.20 & 1.32 & 92.6 & 62.2 & 55.1 & 20.1 & 28.4 \\
\hline$o$-diaminobenzene & 4.61 & 0.37 & 66.8 & 57.2 & 64.2 & 31.0 & 31.5 \\
\hline$m$-diaminobenzene & 5.01 & 0.03 & 36.2 & 42.1 & 35.8 & 13.8 & 7.6 \\
\hline$p$-toluidine & 5.08 & 1.43 & 92.3 & 36.2 & 44.1 & 27.0 & 30.2 \\
\hline$p$-chloroaniline & 3.98 & 1.81 & 31.5 & 24.2 & 22.8 & -0.6 & 6.2 \\
\hline$o$-anisidine & 4.53 & 1.65 & 62.7 & 20.1 & 35.7 & 19.8 & 7.8 \\
\hline$p$-hydroxyaniline & 5.48 & -0.24 & 27.6 & 15.5 & 25.2 & -2.1 & 2.4 \\
\hline aniline & 4.87 & 1.24 & 57.7 & 12.8 & 34.5 & 10.7 & 13.1 \\
\hline$m$-toluidine & 4.71 & 1.59 & 84.2 & 9.7 & 32.9 & 14.9 & 22.0 \\
\hline$o$-toluidine & 4.45 & 1.61 & 75.8 & 9.4 & 20.8 & 10.7 & 7.7 \\
\hline$p$-nitroaniline & 1.02 & 1.19 & 4.7 & 3.0 & - & - & 2.4 \\
\hline$m$-chloroaniline & 3.52 & 1.88 & 19.8 & 0.7 & 2.0 & - & 9.2 \\
\hline$o$-chloroaniline & 2.66 & 2.02 & 8.6 & -4.5 & 1.2 & - & 1.9 \\
\hline
\end{tabular}

$\Delta \mathbf{E}[\mathbf{m V}]=\mathbf{E}_{\mathbf{i}}-\mathbf{E}_{\mathbf{0}} ; \mathbf{E}_{\mathbf{0}}-$ potential recorded in buffer solution, $\mathbf{E}_{\mathbf{i}}-$ potential recorded in the presence of analyte. 